\title{
Recenzja
}

\section{Paweł Bała, Pod wezwaniem Boga czy narodu. Religia a ustrój. Studium przypadku polskich konstytucji, Wydawnictwo Von Borowiecky, Warszawa 2010, ss. 350.}

Tytuł książki wyraźnie wskazuje, że przedmiotem zainteresowania autora jest miejsce religii w konstytucyjnym ustroju państwa. Cel badawczy monografii sprecyzowany został w pytaniu: „Oceniwszy, że los narodu polskiego tak mocno został zdeterminowany przez konkretną religię, pozostaje odpowiedzieć na pytanie: jakie skutki wywarł ten fakt na organizację życia zbiorowego, którego ważnym elementem jest konstytucja? Czy konstytucyjne ustroje państw polskich były w rozwoju dziejowym determinowane przez konfesyjny sposób organizacji życia zbiorowego? Czy ewolucja polskiej myśli ustrojowej na przestrzeni XVIII-XX w. obrazuje przemiany religijne polskiego społeczeństwa?"

Koncepcja rozdziału Kościoła od państwa była przedmiotem długiej debaty w historii. Ustawa zasadnicza z 1997 r., określa zasady relacji między państwem a kościołami i innymi związkami wyznaniowymi w art. 25, który wskazuje na model stosunków państwo - Kościół. Problematyka pozycji prawnej związków wyznaniowych, stosunek państwa do religii i Kościołów była w literaturze przedmiotem wielu opracowań. Nie ma w polskiej literaturze opracowania, które zawiera kompleksową analizę polskich konstytucji pod względem regulacji wyznaniowych. Recenzowana monografia jest pierwszym kompleksowym omówieniem tej tematyki.

Autor przedstawia też problem invocatio Dei różnych konstytucji, co również nie zostało w literaturze przedmiotu szerzej opisane. Problem invocatio Dei w ustawach zasadniczych państwa to problem aksjologiczny ale też antropologiczny, związany z rozumieniem człowieka oraz źródeł moralności i mocy obowiązywania prawa stanowionego. Autor posługuje się terminem nominatio Dei - co stanowi istotne novum w literaturze, a który funkcjonuje w myśli niemieckiej i chyba lepiej oddaje także polską namiastkę invocatio Dei. Różne formy inwokacji przedstawione zostały na przykładzie euro- 
pejskich i pozaueropejskich ustaw zasadniczych, które czerpały inspirację z dziedzictwa religijnego, co nadaje pracy kontekst prawnoporównawczy, i świadczy jednocześnie o szerokiej perspektywie rozważań.

Autor monografii skoncentrował swoje rozważania wokół kwestii wyznaniowych (miejsce religii w polskich ustawach zasadniczych i konstytucyjne podstawy relacji państwo - Kościół) w polskich konstytucjach w rozwoju dziejowym w dwóch płaszczyznach rozważań. Po pierwsze, autor dokonuje analizy regulacji dotyczących religii w wymiarze wspólnotowym i instytucjonalnym, których podmiotem jest Kościół katolicki, inne kościoły i związki wyznaniowe. Rozważania dotyczą przede wszystkim religii chrześcijańskiej - taką perspektywę badawczą autor usprawiedliwia słusznie zakładając, że wyznanie rzymskokatolickie posiada wiodącą pozycję społeczno-polityczną w państwie polskim. Po drugie, dokonana została analiza gwarancji wolności religijnej w wymiarze indywidualnym. Tak sformułowane zadania badawcze obejmują niewątpliwie ważne aspekty podjętej problematyki. Autor zwraca uwagę, że miejsce religii w konstytucyjnych ustrojach determinował fakt, iż była ona pewną metodą życia zbiorowego i analizuje, w jakim wymiarze relacja pomiędzy rzymskim katolicyzmem, a narodem polskim przekładała się na regulacje zawarte w ustawach zasadniczych. Autor skupia się na społecznych i prawnych konsekwencjach katolicyzmu. W aneksie przedstawione zostały katolickie postulaty konstytucyjne. Wydaje się, że postulaty zawarte w drugiej części tego aneksu, a dotyczące człowieka w państwie i wspólnocie, nie mieszczą się w przedmiocie rozważań, o którym autor wspomina we wstępie opracowania.

W celu realizacji zamierzonych celów pracy, oprócz zastosowania metody dogmatyczno-prawnej, zastosowanie znalazła metoda prawno-komparatystyczna (przy porównaniu z innymi konstytucjami, szczególnie invocatio Dei), prawnohistoryczna (w części dotyczącej relacji państwo - Kościół oraz znaczenia rzymskiego katolicyzmu w dziejach narodu polskiego) oraz prawnodoktrynalna. Opracowanie łączy wątki prawnohistoryczne i teoretyczno-prawne. Monografia oparta została na solidnym warsztacie naukowym. W przypisach znajdujemy liczne odniesienia nie tylko do polskiej literatury przedmiotu, co podnosi jej walor poznawczy. Niewiele opracowań dotyczących omawianej materii w takim stopniu odwołuje się do publikacji Anglosasów i Niemców. Autor przywołuje też niezwykle obszerny materiał źródłowy. Niewątpliwie ogromną zasługą autora jest przybliżenie czytelnikowi 
polskiemu regulacji zawartych w licznych europejskich i pozaeuropejskich ustawach zasadniczych.

Struktura opracowania wykazuje pewne oryginalne cechy z punktu widzenia systematyki podręcznika z zakresu prawa. W pierwszej kolejności przedstawia wywód historyczny dotyczący relacji państwo - Kościół, następnie autor omawia związek religii z życiem społecznym narodu polskiego, a w części ostatniej dokonuje analizy regulacji konstytucyjnych we wskazanym zakresie. Znacznie rozbudowana została część trzecia, w której konstytucje polskie podzielono historycznie na dwie grupy - monarchistyczne i republikańskie, i każdej grupie poświęcono odrębny rozdział. Kryterium decydującym była forma ustroju w ujęciu formalnoprawnym. Taki podział uwypuklił aspekt suwerena i pośrednio aspekt aksjologiczny.

Książka poza wstępem i zakończeniem składa się z pięciu rozdziałów, zatytułowanych kolejno: „Kościół a państwo”, „Rzymski katolicyzm w historii narodu polskiego (okres «przedkonstytucyjny»)”, „Konstytucje monarchiczne”, „Konstytucje republikańskie”, „Konstytucja Rzeczypospolitej Polskiej z 2 kwietnia 1997 r.". Bardzo dokładnie i zgodnie z tytułem został ujęty przedmiot badań. Pewien niedosyt budzi brak wyjaśnienia pewnych kategorii pojęciowych, którymi autor się posługuje i odsyła jedynie do pism klasyków. Tezy sformułowane w pracy są z reguły precyzyjne, ale też kontrowersyjne - i zapewne skłonić mogą do podjęcia polemiki. Autor nie zachował pełni naukowego obiektywizmu, co jest niezwykle trudne w kwestiach wyznaniowych.

Pierwszy rozdział pracy omawia relacje państwo - Kościól, w szczególności prezentuje koncepcje rozdziału Kościoła i państwa. Oceny regulacji państwo - Kościół autor dokonał z punktu nauk Carla Schmitta, niemieckiego konstytucjonalisty, który nie jest znany w polskiej nauce prawa, o czym świadczy też zapożyczony sposób narracji. Rozdział pierwszy został poświęcony prezentacji stosunków państwo - Kościół na przestrzeni wieków: począwszy od Średniowiecza przez przeobrażenia jakie postulowało Oświecenie, aż po idee ułożenia stosunków tych dwóch podmiotów przez myśl Soboru Watykańskiego II.

Rozdział drugi traktuje o pozycji religii chrześcijańskiej w historii polskiego narodu. Autor dokonał syntetycznej analizy znaczenia religii chrześcijańskiej w dziejach państwa polskiego w okresie, jak sam określa, „przedkonstytucyjnym”. Myliłby się ten, kto twierdziłby, że autor prezentuje pogląd 
„mesjanistyczny”. W pracy znajdujemy również wątki krytyczne dotyczące stosunków monarchii piastowskiej i jagiellońskiej z Kościołem katolickim.

Rozdziały trzeci i czwarty poświęcone zostały analizie polskich doświadczeń w zakresie regulacji dotyczących relacji państwo - Kościół, zawartych w polskich konstytucjach monarchicznych i republikańskich. Poszczególne akty - począwszy od Ustawy Rządowej aż po obecnie obowiązującą Konstytucję - chronologicznie ujęte zostały w osobnych podrozdziałach, które kolejno przedstawiają racje historyczno-aksjologiczne stanowiące źródło regulacji w zakresie omawianej materii, problematykę określenia suwerena, analizę modelu relacji z związkami wyznaniowymi, a także ujęcie praw jednostki w zakresie wolności sumienia i wyznania.

Autor wskazuje na specyfikę „polskiej myśli ustrojowej” - w odniesieniu do suwerena. Oryginalność polskiego ustroju polegała zatem na dostrzeżeniu podwójnego źródła władzy państwowej: pochodzenia władzy od Boga, czyli uznania, że władza ma swoje źródło nadprzyrodzone i wynika z prawa naturalnego, a z drugiej strony, że wywodzi się z woli narodu, który jako wspólnota podmiotów moralnych jest realizatorem prawa boskiego na ziemi. Pogląd taki obcy był np. myśli ustrojowej Francji, ale też np. Austrii czy Rosji, gdzie wyraźnie przeciwstawiano władzę monarszą, pochodzącą od Boga, tej wyłonionej z woli ogółu, a antagonizm między tymi dwoma metodami legitymizacji władzy był niezwykle silny.

Ostatni, piąty rozdział pracy przedstawia regulacje wyznaniowe w Konstytucji RP z 1997 r. Rozdział ten otwiera analiza modelu relacji państwo - Kościół. Pisząc o równouprawnieniu oraz niezależności i autonomii kościołów i związków wyznaniowych - o konsensualnej regulacji stosunków państwo - związki wyznaniowe zawartej w art. 25 ust. 5 Konstytucji, autor odwołuje się do teorii Habermasa, co stanowi novum w doktrynie - nikt nie kojarzył tej problematyki z teorią komunikacyjnego tworzenia prawa. W drugiej części autor analizuje i przedstawia gwarancje wolności sumienia i religii. Następnie zajmuje się zagadnieniem definicji Narodu w ustawie zasadniczej konkludując, iż niekonsekwencja ustrojodawcy w tym zakresie poddaje wątpliwości możliwość definitywnego twierdzenia, kto jest podmiotem władzy.

Na pytanie: „do jakiej nawiązujemy tradycji, ku czemu pragniemy zmierzać, z jakiej cywilizacji czerpiemy zespół wartości i motywacji, jakie miejsce wyznaczamy w życiu publicznym etyce i moralności" - autor odpowiada, że 
w polskiej przestrzeni społecznej jedynie tradycja chrześcijańska jest na tyle silna i żywotna, by dać podstawę dla moralności publicznej i przeciwstawić się postmodernistycznemu relatywizmowi, w związku z czym Konstytucja RP powinna zawierać formułę uhonorowania Kościoła katolickiego. Zdaniem autora, najsilniejszym nurtem filozoficznym i społecznym stanowiącym fundament scalający wspólnotę narodową jest chrystianizm.

Reasumując, należy stwierdzić, że monografia Pawła Bały stanowi wartościową pozycję, wzbogacającą literaturę naukową z zakresu prawa konstytucyjnego i pewnej mierze wyznaniowego. Opiera się na solidnym warsztacie badawczym. Przy analizie konkretnych zagadnień na gruncie polskim, autor często odnosi się - zarówno w tekście, jak i w przypisach - do rozwiązań przyjętych w innych państwach. Kontrowersyjność niektórych stanowisk autora w stosunku do podejmowanych zagadnień może przyczynić się do dalszych badań w zakresie kształtowania się treści przepisów Konstytucji z 2 kwietnia 1997 r. Nasuwa się pewien zarzut w odniesieniu do niektórych konkluzji autora $\mathrm{w}$ zakresie omawianych kwestii, mianowicie przesadna krytyka braku „uhonorowania” w Konstytucji RP z 1997 r. tradycji religii chrześcijańskiej oraz nieostrych instytucjonalnych regulacji stosunków państwo - Kościół.

Małgorzata Grzesik-Kulesza (Uniwersytet Rzeszowski) 